Gerasimovsky, V. I., Volkov, V. P., Kogarko, L. N., Polyakov, A. I., Saprykina, T. V. \& Balashov, Yu.A. 1966: The Geochemistry of the Lovozero Alkaline Massif, Pt. II (in Russian). Moskva: Nauka, 149-396.

Sørensen, H. 1970: Internal structures and geological setting of the three agpaitic intrusions - Khibina and Lovozero of the Kola Peninsula and Ilímaussaq, South Greenland. Can. Mineral. 10, 3, 299-334.

Sørensen, H., Rose-Hansen, J., Nielsen, B. L., Løvborg, L., Sørensen, E. \& Lundgaard, T. 1974: The uranium deposit at Kvanefjeld, the Ilímaussaq intrusion, South Greenland. Geology, reserves and beneficiation. Rapp. Grønlands geol. Unders. 60, $54 \mathrm{pp}$.

Turekian, K. K. \& Wedepohl, K. H. 1961: Distribution of elements in some major units of the Earth's crust. Bull. geol. Soc. Amer. 72, 175-192.

Institut for Petrologi, University of Copenhagen,

$\emptyset$ ster Voldgade 10,

1350 Copenhagen $K$.

\title{
High zinc contents of sea water in Kangerdluarssuk, the Ilímaussaq area, South Greenland
}

\section{Gert Asmund and John Rose-Hansen}

Samples of sea water were collected in Kangerdluarssuk in the summers of 1974 and 1975 (fig. 28) as part of the geochemical-ecological Narssaq project (Bohse et al., 1975; Nielsen et al., 1976). These have been analysed for dissolved zinc, cadmium, lead and copper by anodic

Fig. 28. Sketch map of the head of Kangerdluarssuk, South Greenland, showing positions of the analysed sea water samples discussed by Asmund \& Rose-Hansen.

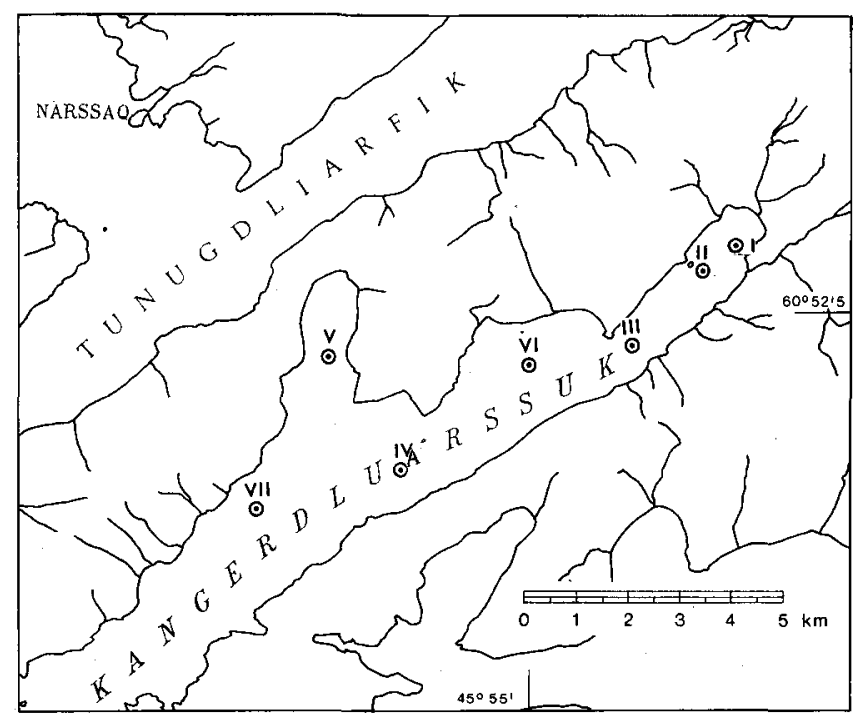


Table 5. Zinc contents in sea water from Kangerdluarssuk, South Greenland

\begin{tabular}{|c|c|c|c|c|c|c|c|c|}
\hline $\begin{array}{l}\text { Dates } \\
\text { of } \\
\text { samp- } \\
\text { ling }\end{array}$ & $\begin{array}{l}\text { Depth } \\
\text { in m }\end{array}$ & I & II & $\begin{array}{ll}t & a \\
\text { III }\end{array}$ & $\begin{array}{l}t \\
\text { IV }\end{array}$ & $\begin{array}{l}0 \\
v\end{array}$ & $V I$ & VII \\
\hline & 0 & 14.8 & 10.4 & 9.7 & 13.6 & 12.2 & 20 & 22 \\
\hline & 5 & 3.7 & 6.5 & 2.0 & 260 & 54 & 31 & 950 \\
\hline \multirow[t]{2}{*}{ July } & 15 & 3.0 & 17.5 & 505 & 34 & 21 & 595 & 2 \\
\hline & 25 & & 7.1 & 10 & 131 & 31 & 29 & 55 \\
\hline \multirow[t]{5}{*}{1974} & 50 & & 3.4 & 12.7 & 88 & 200 & 14 & 34 \\
\hline & 96 & & 4.5 & 1.0 & 40 & 66 & 35 & 168 \\
\hline & 0 & 9 & 2 & 130 & 8 & 37 & 17 & 93 \\
\hline & 5 & 51 & 19 & 65 & 55 & & 7 & 11 \\
\hline & 15 & 32 & 16 & 63 & $<10$ & 33 & $<5$ & 43 \\
\hline \multirow[t]{2}{*}{ May } & 25 & 13 & 84 & & 62 & 35 & $<5$ & 67 \\
\hline & 50 & 35 & 14 & 25 & 120 & 13 & $<5$ & 40 \\
\hline \multirow[t]{6}{*}{1975} & 100 & & 29 & 71 & 120 & 33 & 31 & 55 \\
\hline & 130 & & & & & 85 & & \\
\hline & 150 & & & & & & 25 & 60 \\
\hline & 0 & 6.3 & 7.5 & 3.6 & 6.3 & 12.5 & 5.8 & 18.9 \\
\hline & 5 & 1.3 & 10.1 & 3.1 & 3.6 & 39.1 & 5.7 & 8.7 \\
\hline & 10 & 1.9 & 3.7 & 4.7 & 3.8 & 11.0 & 5.3 & 8.9 \\
\hline Sep- & 15 & 6.9 & 5.1 & 10.6 & 2.6 & 5.1 & 1.7 & 4.0 \\
\hline tem- & 25 & 7.4 & 3.4 & 4.8 & 4.5 & 6.9 & 12.4 & 4.5 \\
\hline \multirow[t]{2}{*}{ ber } & 50 & 5.7 & 5.7 & 5.0 & 7.7 & 34.5 & 5.4 & 4.9 \\
\hline & 75 & & & & & & 4.7 & \\
\hline \multirow[t]{5}{*}{1975} & 90 & & 7.1 & 3.6 & & & & \\
\hline & 100 & & & & 2.3 & 13.7 & & 4.4 \\
\hline & 125 & & & & 3.9 & & & \\
\hline & 150 & & & & & 77 & & 4.9 \\
\hline & 200 & & & & & & & 6.3 \\
\hline
\end{tabular}

stripping voltammetry (Table 5). Water samples were collected with teflon-coated 5 litre Universal Series water samplers with drop messengers (Hydro-bios, Kiel). In 1974 the water samples were taken from GGU motor cutter $N$. V. Ussing, in May 1975 from M/S Adolf Jensen and in September 1975 from a rubber boat. The samples were kept in plastic canisters previously analysed for heavy elements.

The contents of $\mathrm{Cd}$ and $\mathrm{Cu}$ were from less than 0.1 to $0.4 \mu \mathrm{g} / 1$ and less than 0.1 to $1.6 \mu \mathrm{g} / 1$ respectively. These values are in accordance with values reported for sea water elsewhere. The $\mathrm{Pb}$ content was generally less than $0.2 \mu \mathrm{g} / \mathrm{l}$, but a few samples had up to $1.6 \mu \mathrm{g} / \mathrm{l}$ (Rose-Hansen et al., 1977). The content of $\mathrm{Zn}$ is, however, strongly abnormal for sea water varying from 1 to more than $500 \mu \mathrm{g} / \mathrm{l}$. The very high zinc contents found in 1974 necessitated renewed sampling in May and September 1975.

The rocks of the Ilímaussaq alkaline intrusion have high contents of zinc, from an average 
of 0.04 per cent in the naujaites to 0.2 per cent in the lujavrites (Gerasimovsky, 1969; see also Bailey et al., this report) and the bottom sediments of the fjord have contents of $200-1000 \mathrm{~g} / \mathrm{l}$. The province is thus very rich in zinc. The mechanism by which the very high amounts of dissolved zinc have been transferred to the sea water is not yet known. However, we consider that the sampling and analytical errors cannot alone explain the anomaly.

\section{References}

Bohse, H., Larsen, L. M., Rose-Hansen, J., Nielsen, C. O. \& Sørensen, H. 1975: Current research on the Ilímaussaq alkaline intrusion, South Greenland. Rapp. Grønlands geol. Unders. 75, 81-83.

Nielsen, C. O., Rose-Hansen, J. \& Sørensen, H. 1976: Environmental, geochemical and ecological studies in the region around the Ilímaussaq alkaline intrusion, South Greenland. Rapp. Grønlands geol. Unders. 80, 93-97.

Gerasimovsky, V. I. 1969: Geochemistry of the Ilimaussaq alkaline massif (South-West Greenland) (in Russian). Moskva: Nauka, 174 pp.

Rose-Hansen, J., Nielsen, C. O. \& Sørensen, H. (edit.) 1977: The Narssaq project. A geochemical-ecological research project. Progress report no. 1. The 1974 field season vol. I \& II. Inst. Petrology, Univ. Copenhagen, 122 pp.

J.R.-H.,

Institut for Petrologi, University of Copenhagen,

$\emptyset$ ster Voldgade 10,

1350 Copenhagen $K$.

\section{Gravity and rock densities in the Ilímaussaq area, South Greenland}

\section{René Forsberg and Kaare Lund Rasmussen}

Early gravity measurements in South Greenland (Kejlsø, 1958; J. Olsen, personal communication) indicated a large positive Bouger anomaly around Narssaq. Newer terrain-corrected gravity data obtained by the Geodetic Institute as part of regional surveys in the Julianehåb and Godthåb regions showed this anomaly to be approximately over the Ilímaussaq alkaline intrusion. The anomaly is interesting not only because of its size, but also due to the lack of similar anomalies over other Gardar intrusions, such as the Igaliko complex.

The sparse data available (fig. 29) show the residual anomaly is about +30 mgal and 'pulled' away from the centre of the intrusion towards the Narssaq gabbro complex.

To investigate the applicability of a detailed gravity survey for studying the structure of the Ilímaussaq intrusion, a knowledge of density contrast between the different rock types of the intrusion and surroundings is imperative. With this aim, a laboratory density determina- 